ТРАНСФОРМАЦІЯ ІДЕЙ ПРО ДИТЯЧУ ГРУ У СПАДЩИНІ УКРАЇНСЬКИХ ПЕДАГОГІВ (ПЕРША ТРЕТИНА ХХ СТОЛІТТЯ)

\title{
TRANSFORMATION OF IDEAS ABOUT CHILDREN'S GAME IN THE HERITAGE OF UKRAINIAN TEACHERS (FIRST THIRD OF THE XX CENTURY)
}

\begin{abstract}
У статті висвітлено творчий внесок українських педагогів у розвиток теорії і практики дитячої гри (перша третина XX століття). Виокремлено ключові ідеї, чинники впливу на їх трактування педагогами та розроблення методичних рекомендації щодо впровадження гри у практику дошкільного виховання. За результатами історикопедагогічного аналізу архівних документів, наративних джерел розкрито особливості трансформації ідей щодо дитячої гри впродовж означеного періоду. З'ясовано, що в підросійській Україні (1907-1917 роки) теорія гри розроблялася під впливом прогресивних концепцій і методичних систем закордонних педагогів та з урахуванням тогочасних наукових досягнень; гра розглядалася українськими педагогами (Ц. Балтанов, Н. Лубенець, Т. Лубенець, К. Маєвська, І. Сікорський, К. Толмачевська, Е. Яновська) як вроджена потреба та головна умова розвитку дитини дошкільного віку. У теорії дошкільного виховання періоду становлення національної системи освіти (1917-1919 роки) розвиток ідей щодо гри здійснювався в контексті педагогічних положень вільного виховання, індивідуалізації, виховання на українському ґрунті. Гра трактувалася як вільна діяльність дітей, найвища форма природного розвитку, засіб набуття дітьми інтелектуального досвіду, формування здатності до художнього самовиявлення, соціалізації. Значна увага приділялась народним іграм (С. Русова). Упродовж 20-х - на початку 30-х років XX століття мала місце спроба нівелювання ролі гри як природного засобу розвитку дитини в дошкільному віці. У нормативних документах і теоретико-методичних напрацюваннях педагогів (В. Герченштейн, О. Дорошенко, Л. Ейнштейн, С. Лівшина, В. Львов, С. Спаська, Б. Фіш, Ф. Хазіна, Е. Яновська) гра розглядалася як чинник пристосування дітей до соціального оточення й розвитку «трудових звиків, колективіських навичок та революційних дій», як метод ознайомлення дітей $з$ оточенням та їх соціалізації, як одна з форм відтворення трудового побутового оточення й переробки набутого досвіду, як допоміжний засіб комуністичного і політехнічного виховання. Охарактеризовано види, вимоги до добору ігор дітей дошкільного віку. Ключові слова: дитяча гра, рухлива гра, вільна гра, народна гра, гра-забавка, урокгра, ручна «праця-гра», «трудогра».
\end{abstract}

The article highlights the creative work of Ukrainian teachers in the development of theory and practice of children's play (the first third of the twentieth century). The key ideas, factors influencing their interpretation by teachers and the development of guidelines for the introduction of the game in the practice of preschool education are highlighted. According to the results of historical and pedagogical analysis of archival documents, narrative sources revealed the features of the transformation of ideas about children's play during this period. It was found that in sub-Russian Ukraine (1907-1917) the theory of the game was developed under the influence of progressive concepts and methodological systems of foreign teachers and taking into account the scientific achievements of that time; The game was considered by Ukrainian teachers (Ts. Baltanov, N. Lubenets, T. Lubenets, K. Maevska, I. Sikorsky, K. Tolmachevska, E. Yanovska) as an innate need and the main condition for the development of a preschool child. In the theory of preschool education of the period of formation of the national system of education (1917-1919) the development of ideas about the game was carried out in the context of pedagogical provisions of free education, individualization, education on Ukrainian soil. The game was interpreted as a free activity of children, the highest form of natural development, a means for children to gain intellectual experience, the formation of the ability to artistic self-expression, socialization. Much attention was paid to folk games (S. Rusova). During the 20's - early 30's of $X X$ century there was an attempt to level the role of play as a natural means of child development in preschool age. In normative documents and theoretical and methodological developments of teachers (V. Herzenstein, O. Doroshenko, L. Einstein, S. Livshina, V. Lviv, S. Spaska, B. Fish, F. Khazina, E. Yanovska) game was considered as a factor in children's adaptation to the social environment and the development of "work habits, collective skills and revolutionary actions", as a method of acquainting children with the environment and their socialization, as a form of reproduction of working environment and processing of experience, as an aid to communist and polytechnic education. The types and requirements for the selection of games are characterized.

Key words: readiness for innovative pedagogical activity, creative activity, culture, individual culture, culture of self-expression of future educators of pre-school establishments.
Київського університету

імені Бориса Грінченка
Постановка проблеми в загальному вигляді. Усвідомлення того, що гра є природною потребою в дошкільному віці, актуалізує в сучасних нормативних та науково-методичних документах визнання гри як провідної діяльності, що забезпечує набуття дітьми різних видів компетенцій, сприяє розвитку творчих здібностей, самостійності, ініціативності, виникненню дружніх, партнерських сто- сунків, фрормуванню в них стійкого інтересу до пізнання довкілля і реалізації себе в ньому $[1$, с. 3, 7].

3 огляду на актуальність завдань розбудови дошкільної освіти на особистісно-діяльнісних засадах значний інтерес становить теоретикопедагогічна спадщина українських педагогів першої третини XX ст. 3 питань ігрової діяльності дітей дошкільного віку. Вивчення здобутків зна- 
них педагогів, які працювали впродовж зазначеного періоду, може слугувати для виокремлення й творчої адаптації перспективних ідей в сучасному дошкіллі.

Аналіз останніх досліджень і публікацій. Здійснений історико-педагогічний аналіз показав, що окремі аспекти означеної проблеми є предметом досліджень сучасних науковців: рухливі та вільні ігри як засіб розвитку ініціативи, франтазії, творчості в теоретико-практичній спадщині О. Дорошенко (О. Венгловська); генеза діяльнісного підходу до навчання і виховання дітей дошкільного віку (Г. Іванюк); дитяча гра у практиці суспільного дошкільного виховання кінця XIX - початку XX ст. (М. Головко, Г. Димова); гра як засіб соціалізації дітей дошкільного віку у працях С. Русової (Р. Новгородський); гра як засіб оздоровлення дітей у педагогічному доробку К. Толмачевської (А. Січкар). Однак зазначена проблема в окреслених хронологічних межах $€$ малодослідженою. Це визначило тематику пропонованої розвідки.

Виділення не вирішених раніше частин загальної проблеми. Як засвідчують історикопедагогічні студії наукових джерел, подальшого вивчення й систематизації потребує питання впливу наукових та суспільно-політичних чинників на розвиток педагогічної думки про гру у фрормуванні особистості дитини дошкільного віку.

Мета статті - дослідити творчий доробок українських педагогів (перша третина XX ст.) щодо гри як природної потреби дитини дошкільного віку, трансорормацію їхніх поглядів залежно від суспільно-політичних умов.

Виклад основного матеріалу. Наприкінці XIX - на початку XX ст. в теорії дошкільного виховання країн Європи, Америки й імперської Росії гра розглядалася як вроджена потреба та головна умова розвитку дитини-дошкільника. Аналіз наукових праць і публікацій означеного періоду (Ц. Балтанов [14], Н. Лубенець [6], К. Маєвська [12], С. Русова [16], І. Сікорський [19], К. Толмачевська [9], Е. Яновська [24; 25]) дає підстави стверджувати, що українські вчені поділяли вищезазначені ідеї європейської й американської наукової думки

У плеяді українських педагогів чільне місце належить І. Сікорському. У праці «Виховання у віці першого дитинства» (1884 р.) він розвинув ідею природної необхідності гри в дошкільному віці та ії̈ значення в розвитку дитини. І. Сікорський зазначав, що «гра для дитини - це не тільки забава, а й розумова праця, школа мислення, де даються конкретні знання про предмети, про причиннонаслідкові зв'язки явищ» [19, с. 36].

Думки І. Сікорського стосовно особливого значення рухливої гри в розвитку дитини дошкільного віку знайшли своє відображення і розвиток у працях Е. Яновської «Виховні засоби дитячого садка» (1911р.) [24], Н. Лубенець «Народний дитячий садок» (1911р.) [6], К. Толмачевської «Літні майданчики в 1912 р.» [9]. Зокрема, у праці «Виховні засоби дитячого садка» (1911р.) Е. Яновська констатувала, що у процесі рухливої гри дитина не тільки рухається, а «живе всім своїм єством», переживає масу вражень, які спонукають її думати, розвивають кмітливість і закладають основи моральності [24, с. 541]. Рухливі ігри, які задовольняють насамперед природну потребу дітей в організованих рухах, як зазначала Н. Лубенець у публікації «Народний дитячий садок» (1911р.), сприяють фрормуванню самоконтролю, зародженню почуття відповідальності за свої вчинки, викликають товариськість і доброзичливе ставлення до однолітків [6, с. 230].

Суголосні вищезазначеним погляди К. Толмачевської. Педагог уважала, що тільки у грі можна пізнати справжню сутність дитини, виявити творчі задатки, розвинути їі фрізично, розумово, морально, а на основі соціальних інстинктів сорормувати здатність до співжиття у громадянському суспільстві. Педагог підкреслювала значення гри в дошкільному дитинстві та зазначала: «Коли надали дитині можливість гратися, ми нічого нового для неї не винайшли, бо гра - головний зміст дитячого життя» [9, с. 10].

Нові підходи до обґрунтування гри подано К. Толмачевською у праці «Літні дитячі майданчики в 1912 р.»: 1) відмова від «строгої реґламентації» ігрової діяльності дітей; 2) урахування можливостей дітей у доборі рухливих ігор, щоби «<...> забезпечити поступове застосування наявних у них сил, знань і енергій та подальший гармонійний розвиток»; 3) відмова від застосування під час проведення ігор покарань та винагород; 4) участь керівниці у грі на правах «старшого товариша», до авторитету й допомоги якого діти можуть звернутися у складних ситуаціях. К. Толмачевська висвітлила новий погляд стосовно розширення фрорм організації діяльності дітей, що здатні задовольнити природні потреби дитячого організму в русі, роботі м'язів, у грі. В основу виховної роботи 3 дітьми на літніх майданчиках ця дослідниця поклала систему ігор і занять П. Лесгафта, згідно 3 якою «<...> у грі дитина живе і водночас готується до життя» [9, с. 6].

У контексті дослідження заслуговує на увагу висвітлення гри як форми організації навчання в дитячому садку, зроблене Ц. Балтановим, С. Русовою, Е. Яновською. У доповіді Ц. Балтанова «Урок-гра в дитячому садку», що ввійшла до «Звіту Київського товариства народних дитячих садків за 1908 р.» (1909р.) [14], центральне місце в організації навчання дітей віком від 4-х до 8-ми років педагог відводив уроку-грі. Усі частини урокугри, об'єднані однією метою, передбачають різну діяльність дітей: рухову, мовну, музичну, ігрову, 
образотворчу. Чергування різних видів діяльності, на думку доповідача, запобігає втомлюваності дітей, забезпечує «суцільне радісне задоволення». Також під час уроку-гри «діти отримують цілу низку виховних і освітніх вражень, переживають водночас здорові почуття» [14, с. 57].

Деякою мірою С. Русова поділяла думки Ц. Балтанова і вважала, що успішну організацію виховання й навчання дошкільників можливо здійснити за умови максимального наближення до гри, що сприятиме зацікавленню та захопленню дітей. «Найперше виховання дитині можна дати грою, а найпершу науку зробити такою ж цікавою, як гра», - зазначала вона [16, с. 8].

Великого значення грі як ефективному засобу закріплення навчального матеріалу, який діти засвоюють під час організованих занять, надавали К. Маєвська й Е. Яновська. На їхнє переконання, гра дає можливість дітям відтворити всі отримані ними враження в діях, що забезпечує активне засвоєння побаченого та почутого. Е. Яновська вважала за доцільне впроваджувати у практику роботи дитячого садка різні види ігор, як-от: ігри, у яких діти наслідують навколишню дійсність; ігри на застосовування отриманих знань; творчі, рухливі ігри [24, с. 542; 25, с. 599]. К. Маєвська особливого значення надавала драматизації та зазначала, що «<..> коли розігрування дітьми казок, оповідань відбувається за активної участі дітей, то жодний спосіб повторення й закріплення вражень не може зрівнятися 3 ним за силою і яскравістю дитячих переживань» $[12$, с. 40].

Ідея щодо гри як вродженої потреби та головної умови розвитку дошкільника відображена у програмно-методичному забезпеченні, створеному сподвижниками дошкільного виховання означеного періоду: Н. Лубенець, «План бесід, предметних уроків і занять у дитячому садку» (1907 р.) [13]; Н. Лубенець, «Орієнтовна програма занять у дитячому садку» (1908 р.) [7]; К. Маєвська, «Програма занять у дитячому садку» (1911-1912 рр.) [12].

Актуальні для сьогодення українського дошкілля, як і в період Української Народної Республіки (1917-1919рр.), думки С. Русової щодо гри, викладені у праці «Дошкільне виховання» (1918 р.), розвинуті в контексті положень вільного виховання, індивідуалізації, виховання на українському ґрунті. Педагог розглядала гру як найвищу форму природного розвитку дитини. Науковим підґрунтям теоретичних положень С. Русової стосовно гри як провідного чинника виховання й розвитку дітей дошкільного віку були дослідження відомого на той час ученого Болдвина. Він розкривав педагогічну вартісність гри 3 погляду біогенетичного напряму в науці й інтерпретував гру найбільш доцільною формою природного розвитку, що забезпечує «фрормування гнучкого тіла і швидкого розуму» [17, с. 77].
С. Русова характеризувала дитячу гру як: 1) вільну діяльність, яка найкраще задовольняє вимогу дитинства щодо активності й різноманітних рухів; 2) привабливий, «активно-мрійний процес», який приносить дитині задоволення; 3) діяльність, що потребує від дитини самостійної, активної творчої думки, яка дає можливість «переймати» не механічно, а свідомо, утворюючи свої комбінації рухів, образів, відношення живих істот і неживих речей. Педагог зазначала, що дитина, захоплена грою, упродовж тривалого часу активно діє, творчо використовує свій досвід, набутий під час спостережень навколишнього, що $€$ свідченням роботи розуму в поєднанні з руховою активністю [17, с. 73-80].

Трактування С. Русовою гри як вільної діяльності дітей зумовило й особливий погляд педагога на гру як на метод навчання. Вона підкреслювала винятково велике значення гри в розвитку дітей, водночас уважала недоцільним використовувати гру як метод подачі знань під час навчання арифметики, грамоти. Своє бачення С. Русова пояснювала тим, що в цьому разі метод гри набуватиме штучного характеру і не зможе задовольнити дітей, адже гра, яка проводиться під керуванням дорослих, втрачає важливий напрям - вільне психологічне творче виявлення самої дитини [17, с. 81].

С. Русова розглядала гру крізь призму психологічних знань про дитину та вважала доцільним відразу після екскурсії перетворити на забавку всілякі події, пережиті дітьми під час екскурсії. Педагог зазначала, що така гра-забавка викликає «реорлекторний спомин», сприяє кращому запам'ятовуванню побаченого й почутого під час екскурсії [17, с. 79-80].

У теорії національного дошкільного виховання С. Русової набули подальшого розвитку думки Н. Лубенець, І. Сікорського, К. Толмачевської щодо рухливих ігор як засобу всебічного розвитку дітей. Зокрема, педагог зазначала, що «руханки» сприяють зміцненню м'язів, координації рухів, здатності продукувати творчу енергію; допомагають формуванню вольової та моральної поведінки, викликати в дитини «працю різних інтелектуальних сил». Внеском педагога в розвиток теорії та практики дошкільного виховання є підготовлена нею низка народних ігор для дітей, які вона радила проводити в різні пори року [18, с. 188-192].

Ідея гри як найвищої форми природного розвитку дитини в контексті положень вільного виховання, індивідуалізації, виховання на українському ґрунті впроваджена у змістово-методичних матеріалах: «Порадник діячам позашкільної освіти і дошкільного виховання» (1918р.) [15], «У дитячому садку» (1919 р.) [18].

На основі рішень Першої всеукраїнської наради 3 народної освіти з березня 1920 р. було визначено новий стратегічний державний курс, 
спрямований на соціальне виховання дітей. Ідея гри як діяльності, що є природною потребою дітей дошкільного віку та запорукою їхнього повноцінного розвитку, по-різному трактувалася в педагогіці радянського періоду 20-30-х рр. XX ст. О. Дорошенко характеризувала гру як природну діяльність дитини дошкільного віку, розвивала теорію гри в руслі соціального виховання. Педагог зазначала, що все виховання дитини мусить будуватися на іграх, бо гра є природним засобом розвитку соціального інстинкту. Особливого значення в розвитку самостійності, ініціативи дітей О. Дорошенко надавала рухливим та вільним іграм [2, с. 5-9]. О. Дорошенко спирається на педагогічні положення профресора С. Ананьїна, матеріали практичного досвіду дошкільних установ і доводить, що основним засобом соціального виховання дітей і організації дитячого колективу дошкільного віку $€$ колективна гра: «Як усі свої інші перші вмілості дитина одержує самовільно, шляхом переймання та гри, так і набуття елементарного вміння жити організовано, опанування перших спроб самоврядування діти мусять дістати під час гри» [3, с. 26].

У педагогічній літературі 20-х рр. XX ст. мали місце думки щодо ототожнення гри із працею дітей. Зокрема, А. Шевалова зазначала, що «<...> найбільш важливим трудовим процесом дитячого колективу є гра, завдяки якій розвиваються і закріплюються пізнавальні здібності, фрормується активне суспільне життя [23, арк. 496]. У публікації В. Львова «Ігровий процес у дошкільному віці» (1929 р.) [10] спостерігається суголосність вищезазначеним думкам А. Шевалової. Автор стверджує, що важко провести межу між працею дитини і грою, бо дитина не може сприймати дійсність по-справжньому; вона перетворює ії по-своєму, «по-дитячому, тому трудиться й тоді, коли грається, й тоді, коли столярує» [23, с. 126].

Г. Шумахер розглядала гру як засіб освіти, «який у своєму методичному значенні важливіший від праці» [22, с. 52]. Л. Ейнштейн у публікації «Розмови про виховання дітей» (1930р.) [5] наголошував на значенні гри в розумовому розвитку дитини й ознайомленні її з навколишнім життям. Він писав, що у грі дитина задовольняє природну потребу рухатися, розвиває м'язи, емоції, навчається орієнтуватися в оточенні [5, с. 9-12].

У педагогічній теорії початку 30-х рp. XX ст. окремі педагоги вважали ці думки такими, що суперечать марксистсько-ленінській методології, згідно 3 якою активність, сприйнятливість, розумовий розвиток дитини забезпечуються суто виховним процесом, а не закладені «біологічним фрондом». Свідченням цього є публікація Б. Фіш, Ф. Хазіної «Проти біологізації дошкільника» (1932р.) [20]. Її автори зробили аналіз поглядів С. Спаської на гру як на «природний прояв діяльності» дитини, засіб розумового розвитку, убачали в них прихований біогенетичний закон педоцентризму, буржуазну теорію саморозкриття дитини. Автори вважали неприйнятним вирішення завдань пролетарського виховання й ознайомлення дітей соціалістичними методами праці шляхом гри. Думки С. Спаської щодо гри як провідного виду діяльності дошкільників вони розглядали як ворожі наміри «відірвати» дітей від реальної трудової дійсності, участі в соціалістичному будівництві, підміни грою всього життя дитини [20, с. 58-59].

Аналіз наукових джерел початку 1930-х рр. свідчить про спроби вирішити проблему політехнізму в дошкільній установі шляхом «трудогри». У статті «Політехнізм у дитячому садку» (1930р.) [11] В. Львов виклав думки стосовно того, що коли до дитячих трудових процесів додати ігрову діяльність, то елементами політехнізму можна охопити всі форми дитячої поведінки. На його думку, «переплітаючи гру із працею, діти непомітно для себе набувають всіх потрібних їм знань і вмінь» [11, с. 31-32]. Ці погляди не знайшли одностайної підтримки в педагогів. У статті «До питання про політехнічне виховання дітей дошкільного віку» (1931 р.) [8] С. Лівшина та В. Герценштейн піддали різкій критиці «трудогру» як непродуктивну за своєю суттю, що ізолювала дітей від усього виробничого оточення, замикала їх у вузько обмежені, окремі для кожного кола інтереси, без їхньої соціально перспективної значущості, не сприяла політехнізації [8, с. 21].

Нівелювання ролі гри як природного засобу розвитку дитини відображено у змістово-методичному забезпеченні дошкільних установ, як-от: «Циркулярний лист для керівництва» (1921р.) [21], робоча книга для вихователів дитячих садків «Дошкільне виховання» (1927р.) [26]; «Дошкільне виховання. Матеріали до Порадника» (1928 р.) [4].

Висновки. Історико-педагогічне дослідження розвитку ідей про дитячу гру у спадщині українських педагогів в означених хронологічних межах (перша третина XX ст.) уможливило твердження про трансформацію їх під впливом наукових досягнень та суспільно-політичних умов. З'ясовано, що впродовж 1907-1919 рр. актуальною була ідея щодо гри як вродженої потреби та головної умови розвитку особистості дитини. Однак у 20-х - на початку 30-х рр. XX ст. ця ідея трансформувалася відповідно до суспільно-ідеологічних запитів, стратегій розвитку радянської системи дошкільного виховання. Віяння нового часу применшували значення гри в житті дитини, висували на перший план практичні трудові та суспільні навички, політичну освіту. Засобом гри передбачалося фрормувати «соціально-політичні орієнтації», забезпечувати становлення класової свідомості, «робити внесок у політехнічне виховання». Творче переосмислення і розвиток спадщини українських педагогів сприятимуть еорективному використанню потуж- 
ного потенціалу гри в сучасному українському дошкіллі. Цікаві для подальшого вивчення ідеї щодо гри як засобу фрормування базових якостей та соціалізації особистості.

\section{БІБЛІОГРАФІЧНИЙ СПИСОК:}

1. Базовий компонент дошкільної освіти / авт. кол. : А. Богуш (наук. керівн.) та ін. Київ, 2012. 30 с.

2. Дорошенко О. Дитячий садок. Київ, 1922. 217 с.

3. Дорошенко О. Організація дитячого колективу в ранньому дитинстві. Радянська освіта. Харків : Шлях освіти, 1923. № 2. С. 12-27.

4. Дошкільне виховання : матеріали до порадника. НКО УСРР. Харків : ДВУ, 1928. 192 с.

5. Ейнштейн Л. Розмови про виховання дітей Харків : Наукова думка, 1930. 30 с.

6. Лубенец Н. Народный детский сад. Дошкольное воспитание. 1911. № 4. С. 222-232.

7. Лубенец Н. Примерная программа занятий в детском саду. Отчет о деятельности Киевского общества народных детских садов за 1908 г. Киев, 1908. С. 77-85.

8. Лівшина С., Герценштейн В. До питання про політехнічне виховання дітей дошкільного віку. За комуністичне виховання дошкільника. 1931. № 1/2. C. 21-23.

9. Летние площадки для детских игр: отчеты руководительниц-фрребеличек Киевского фрребелевского института и доклад преподавательницы института Е.А. Толмачевской / под. ред. В. Флерова. Киев : Изд. В.А. Флерова, 1913. 65 с.

10. Львов В. Ігровий процес в дошкільному віці. Шлях освіти. 1929. № 3. С. 124-129.

11. Львов В. Політехнізм у дитячому садку. Радянська освіта. 1930. Ч. 10. С. 31-32.

12. Маевская К. Программа занятий в детском саду. Дошкольное воспитание. 1913. № 1. С. 39-42.
13. Народный детский сад (с приложением отчета о деятельности детского сада, приюта и школы нянь за 1906 г). Киев : Тип. Кушнерев И.Н. и К., 1907. 96 с.

14. Отчет о деятельности Киевского общества народных детских садов за 1908 г. Киев : Тип. Кушнерев И.Н. и К., 1909. 86 с.

15. Порадник діячам позашкільної освіти і дошкільного виховання. Київ, 1918. Вип. 1. 175 с.

16. Русова С. Дошкільне виховання. Світло. 1913. Кн. 3. C. 7-14.

17. Русова С. Дошкільне виховання. Вибрані педагогічні твори. Київ : Освіта, 1996. С. 34-185.

18. Русова С. У дитячому садку. Вибрані педагогічні твори. Київ : Освіта, 1996. С. 185-202.

19. Сикорский И. Воспитание в возрасте первого детства. Санкт-Петербург, 1884. 99 с.

20. Фіш Б., Хазіна Ф. Проти біологізації дошкільника. За комуністичне виховання дошкільника. 1932. № 3. С. 58-59.

21. Циркулярний лист для керівництва // Центральний державний архів вищих органів влади та управління України. Ф. 166. Оп. 2. Спр. 539. Арк. 102-102 зв.

22. Шумахер Г. Методичні позиції дошкільництва Німеччини. Шлях освіти. 1928. № 4. С. 49-56.

23. Шевалова А. Дослідна робота в дитячому садку № 8 м. Одеси // Центральний державний архів вищих органів влади та управління України. Ф. 166. Оп. 4. Спр. 339. Арк. 496-497.

24. Яновская Э. Воспитательные средства детского сада. Дошкольное воспитание. 1911. № 7. C. $540-543$.

25. Яновская Э. Воспитательные средства детского сада. Дошкольное воспитание. 1911. № 8. C. 597-606.

26. Яновська Е., Панченко Н., Рабинович X. Дошкільне виховання. Харків : Книгоспілка, 1927. $187 \mathrm{c}$. 